\title{
Research on Coal Bed Methane (Gas) Occurrence Controlled by Geological Tectonics in the Southern Margin of North China Plate: A Case Study of the Pingdingshan Coalfield, China
}

\author{
Jiangwei Yan $\mathbb{D}^{1},{ }^{1,2,3}$ Zhihong Tan $\mathbb{D}^{1,}{ }^{1,2,3}$ Yan Guo $\mathbb{D}^{4},{ }^{4}$ and Tianrang Jia $\mathbb{D}^{1,2,3}$ \\ ${ }^{1}$ State Key Laboratory Cultivation Base for Gas Geology and Gas Control (Henan Polytechnic University), Jiaozuo 454003, China \\ ${ }^{2}$ College of Safety Science and Engineering, Henan Polytechnic University, Jiaozuo 454003, China \\ ${ }^{3}$ Collaborative Innovation Center of Coalbed Methane and Shale Gas for Central Plains Economic Region, Jiaozuo 454003, \\ Henan Province, China \\ ${ }^{4}$ School of Emergency Management, Henan Polytechnic University, Jiaozuo 454003, China \\ Correspondence should be addressed to Zhihong Tan; tanzhihong@hpu.edu.cn
}

Received 23 December 2020; Revised 17 January 2021; Accepted 8 February 2021; Published 4 March 2021

Academic Editor: chao xu

Copyright (C) 2021 Jiangwei Yan et al. This is an open access article distributed under the Creative Commons Attribution License, which permits unrestricted use, distribution, and reproduction in any medium, provided the original work is properly cited.

\begin{abstract}
The geological structure is complex in the plate margin zone, and the occurrence of coal bed methane (CBM) is nonuniform with an obvious zoning phenomenon. It plays an important role to reveal the spatial distribution of CBM and its influence factors in plate margin zone for CBM exploitation and gas disaster prevention in coal mines. Based on the data of gas emission during mining, CBM content, and gas pressure in the Pingdingshan Coalfield, lying on the south edge of North China plate, the distribution characteristics of CBM and its influence factors using theories of CBM (gas) geology and statistical analysis method are investigated. The research area is divided into four CBM occurrence belts. There are its own CBM occurrence feature and control structural type in each CBM belt. Likou syncline is the structure that controls the overall distribution of CBM. NWtrending fold-fault belt, Guodishan fault, and Jiaxian fault are the structures that control the CBM occurrence in CBM belt IV, CBM belt II, and CBM belt I, respectively. And the difference in structural types is the main factor of CBM zoning.
\end{abstract}

\section{Introduction}

CBM (gas) is generated from and stored in the coal seam . It is not only a kind of disastrous gas for coal mining but also a kind of clean energy. The law of CBM (gas) occurrence and its influence factors are important bases for the exploitation of CBM and the prevention of gas disaster in the coal mine. Lots of researches have been done on the correlation between CBM (gas) occurrence and its influence factors such as geological tectonic, coal rank, coal seam thickness, overburden depth of coalbed, tectonic stress, and wall rock. Geological tectonic is a basic and important factor of them, which controls not only the formation and evolution of coal-bearing basins and coalbearing strata but also the generation, preservation, and accumulation of CBM (gas).
Creedy (1988) pointed out that the geological tectonic is the main influencing factor for the occurrence and distribution of CBM (gas), which controls the characteristics of CBM occurrence and distribution [1]. Gayer and Harri (1996) put forward seven geological factors controlling CBM rich, such as tectonic, overburden depth of coal seam, coal rank, the thickness of coalbed, CBM (gas) content, and hydrogeology [2]; geological tectonic is a basic factor of them [3]. Bibler et al. pointed out that the tectonic movement affects not only the generation conditions of CBM (gas) but also the preservation conditions of it when studying worldwide coal mine methane emissions [4]. Frodsham et al. believed that the coal seam is compressed and sheared under tectonic action, the coal seam was destroyed, and the deformed coal, which is favorable for CBM (gas) preservation and provides a carrier for CBM (gas) enrichment, was 
developed [5, 6]. Yang found that there is a close relation between faults and gas emission in the Jiaoxi Mine of the Jiaozuo mining area [7]. Cao and Peng pointed out that the deformed coal area formed along the coal seam fault is a high gas accumulation area [8]. Zhang et al. found $[9,10]$ that the multiple tectonic evolutions of coal-bearing strata and the geological conditions formed by it are important geological factors affecting CBM generation, migration, preservation, and coal-gas outburst. Tectonic compression and shear activities will cause deformation and damage of coal seam, and it is conducive to form deformed coal and closed environment, which is apt to preserve CBM (gas). Tectonic extension, rifting activities, and tectonic uplift will make a large amount of CBM (gas) released. Jia et al. analyzed the tectonic control law of coalbed gas occurrence in Guizhou, Liaoning, Yunnan provinces, divided the different coalbed gas zones, and believed that the geological structure and its evolution controlled the characteristics of coal seam gas zones [11-13]. In summary, the current CBM (gas) occurrence is caused by many factors, but geological tectonics is a basic and key factor. The compressive and compressshear geological tectonics zones are easy to have a gas outburst and enrich CBM (gas); extensional and rifted geological tectonics are easy to release CBM and often lead to low CBM (gas) content in those regions. The CBM (gas) occurrence is stepwise controlled by geological structure, which caused CBM (gas) to exhibit partition and zonation $[9,10,14]$.

There are seven geological eras coal-bearing strata in China. The coal-bearing strata in different geological times experienced different tectonic movements; the degree of the coal-bearing strata deformed and displaced by compression, extension, and shear is different. The development degree of geological structure and the conditions of CBM (gas) generation, migration, and preservation are greatly different. For example, Permo-Carboniferous coal-bearing strata, formed early, mainly experienced the actions of Indosinian, Yanshan, and Himalayan tectonic movements and the present tectonic stress field. Generally, there are high CBM (gas) content and gas pressure and serious coal-gas outburst in the coal seam of PermoCarboniferous. And the coal-bearing strata formed in different geological times in China are located in different geotectonic positions, with different degrees of plate tectonism and different regional geological tectonic evolution background, which makes the sedimentary environment, in situ stress field, and temperature field different, thus making the generation and preservation conditions of CBM (gas) different. Despite the different positions of the same mining area, CBM (gas) occurrence has also obvious differences. The occurrence of CBM (gas) is nonuniform, and there is an obvious zonation phenomenon. According to the actual situation of coal mine gas and regional geological structure in China, Zhang et al. (2013) put forward 10 geological structure controlling types for the coal mine gas (CBM) occurrence in China, and the whole coalfield in China was divided into 29 areas [15]. The coal seams in the south edge of North China plate are classified as high (CBM) gas and serious coal-gas outburst area [15]. Pingdingshan Coalfield is located in this area [16], $40 \mathrm{~km}$ along the east-west direction and $20 \mathrm{~km}$ along the north-south direction, with a total area of
$650 \mathrm{~km}^{2}$ [17]. It is an important coal production base of China. But it has complex geologic structures, high CBM (gas) content and gas pressure, and serious risk of coal-gas outburst [14]; the law of CBM (gas) occurrence and its control factors are yet not clarified, which seriously affects the production safety of coal mine. With the development of deep mining in recent years, the gas extraction and CBM development are more and more difficult, and the risks of coal-gas compound dynamic disasters are increasingly aggravating $[18,19]$. More studies on the relationship between CBM (gas) occurrence and geological structure should be done. Based on the actual measured CBM (gas) data and geological data in the Pingdingshan Coalfield, this study investigated CBM (gas) occurrence laws and its control factors and predicted CBM (gas) distribution in deep areas, which offered significant guidance for CBM development and control of gas disasters in coal mine.

\section{Geological Setting}

The Pingdingshan Coalfield lies on the south edge of the North China plate and the north side of the northern boundary faults $F_{1}$ of the Qinling orogenic belt [20]. It is a typical representative of all coalfields on the south edge of the North China plate and is also controlled by the Qinling orogenic belt (Figure 1).

Likou syncline is a main tectonic in Pingdingshan Coalfield, which is stretched toward the NW-SE direction (Figure 2(a)). The axis of the syncline crosses the whole coalfield from southeast to northwest and its two wings are basically symmetric (Figure 2(b)). The syncline is relatively convergent and closed in the southeast and wide and gentle in the northwest. There are a series of WNW-trending and $\mathrm{NW}$-trending fold structures and fault structures parallel to the Likou syncline axis on the two wings and the periphery of the coalfield. There are also some NEN-trending and NEtrending faults along with the NW-trending structure. In the eastern part of the coalfield, fold structures are especially developed. From south to north, there are mainly Niuzhuang syncline, Guozhuang anticline, Baishishan anticline, Lingwushan syncline, and Xiangjia anticline [14]. The southern boundary of the coalfield is a coal seam outcrop, and the northern, western, and eastern boundaries are Xiangjia fault, Jiaxian fault, and Luogang fault, respectively (Figure 2(a)). These boundaries' faults with large angles and high fall make Pingdingshan Coalfield a separate horst structure unit. A complete set of Carboniferous-Permian coal-bearing strata was deposited in Pingdingshan Coalfield. It is a multiseam coalfield with a total thickness of more than 30 meters. D, E, F, and G coal formations are the main minable coal seams with about $15-18 \mathrm{~m}$ coal thickness (Figure 2(c)). The research area lies on the SW wing of Likou syncline in the Pingdingshan Coalfield (Figure 2(a)).

\section{Characteristics of CBM Occurrence}

From the actual situation of coal mining such as gas emission and the measured data of CBM (gas) parameters including CBM content (from [21]) and gas pressure (Table 1), there are obvious differences in CBM content, gas 


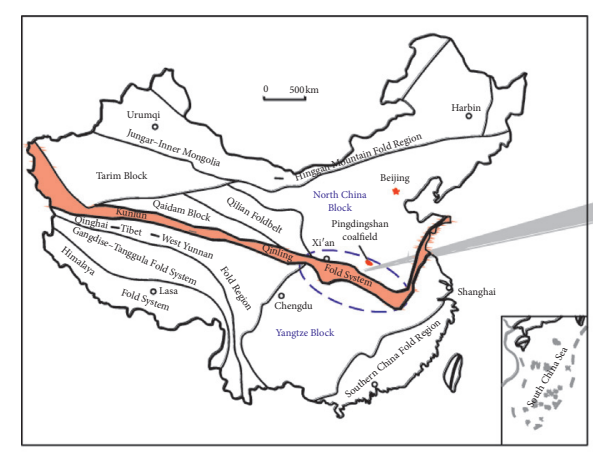

(a)

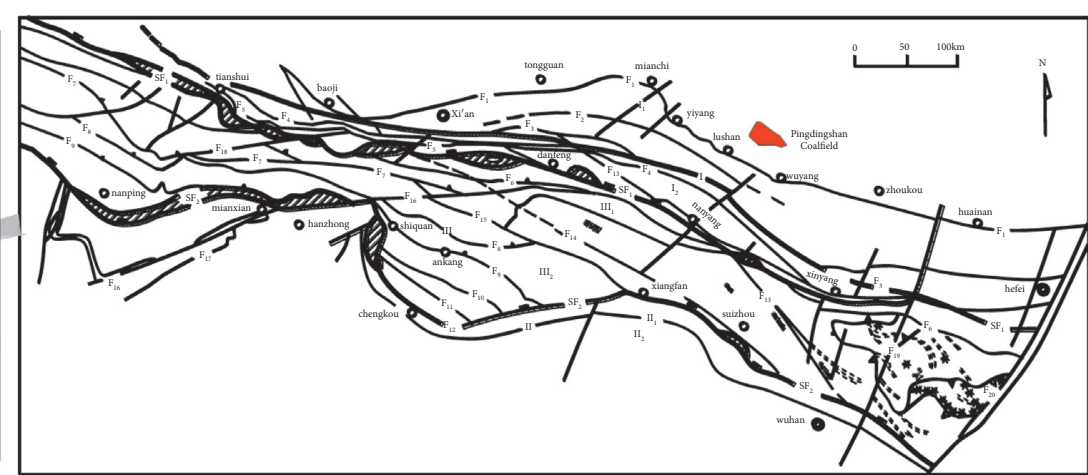

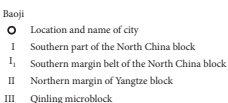

(b)

FIgURE 1: The geotectonic location of Pingdingshan Coalfield with (a) geotectonic units of China and geographical location of Pingdingshan Coalfield and (b) tectonic units of Qinling orogenic belt and geographical location of Pingdingshan Coalfield.

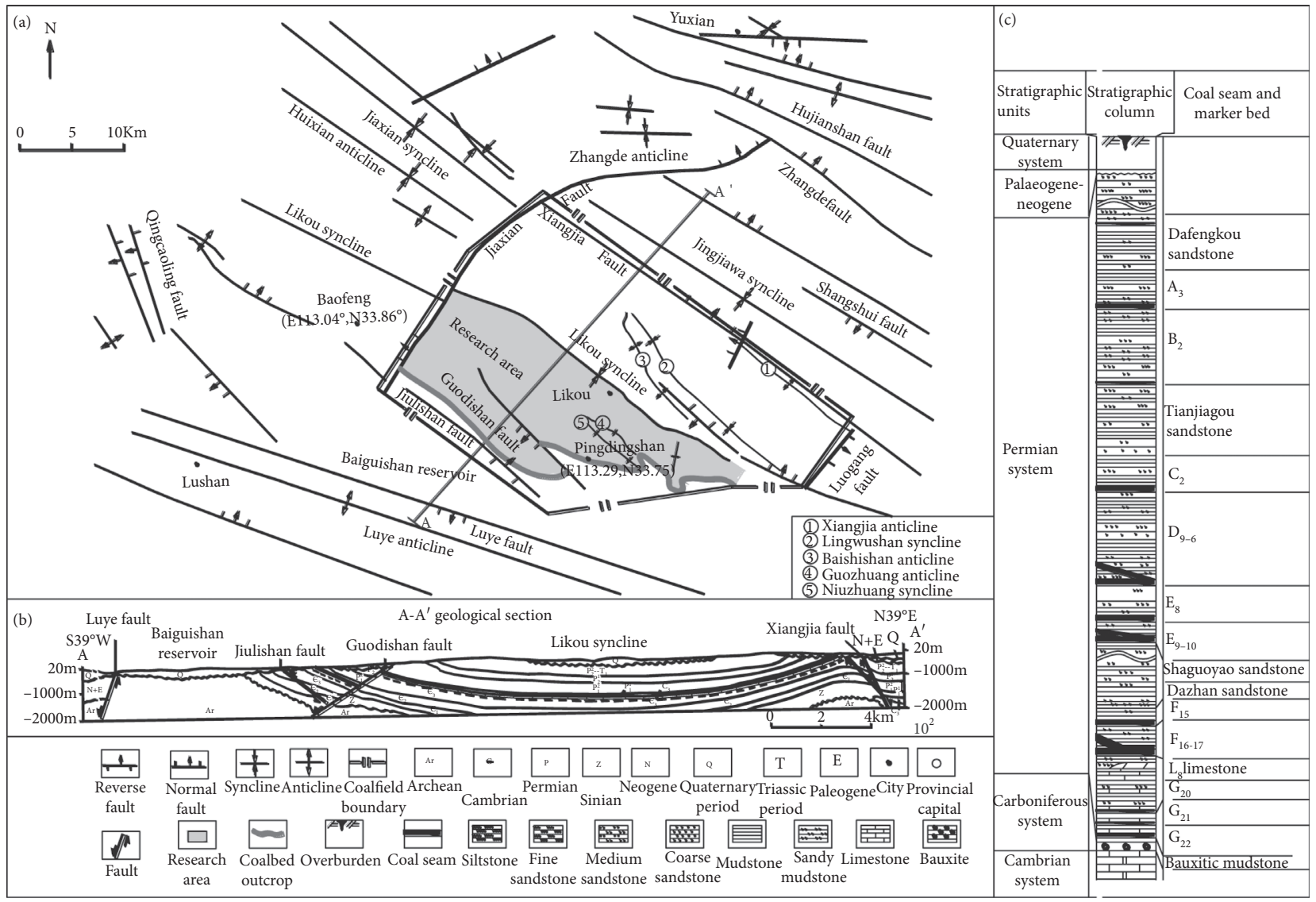

Figure 2: Geological setting and the position of the research area.

pressure, and gas emission among the western, middle, and eastern parts of the research area. CBM occurrence shows zonation characteristics. The research area is divided into four CBM occurrence belts. At the same burial depth, CBM content, gas pressure, and gas emission generally increase firstly, then decrease, and increase again from west to east (Figures 3 and 4, Tables 2 and 3).

CBM belt $I$ is located in the west of Pingdingshan Coalfield and mainly includes Xsh Mine and the west of No.11 Mine. CBM belt II is also located in the west next to 
TABLE 1: The representative gas pressure of the research area in coal seam group F.

\begin{tabular}{|c|c|c|c|c|c|c|c|c|}
\hline Number & Gas pressure $(\mathrm{MPa})$ & Burial depth (m) & Number & Gas pressure $(\mathrm{MPa})$ & Burial depth (m) & Number & $\begin{array}{c}\text { Gas } \\
\text { pressure }(\mathrm{MPa})\end{array}$ & $\begin{array}{c}\text { Burial } \\
\text { depth }(\mathrm{m})\end{array}$ \\
\hline 1 & 0.7 & 970 & 36 & 1.69 & 1148 & 71 & 2.9 & 831 \\
\hline 2 & 0.57 & 985 & 37 & 2.1 & 1039 & 72 & 1.07 & 475 \\
\hline 3 & 0.35 & 923 & 38 & 2.5 & 1106 & 73 & 1.15 & 525 \\
\hline 4 & 0.22 & 1020 & 39 & 2.6 & 1039 & 74 & 2.06 & 575 \\
\hline 5 & 0.57 & 1026 & 40 & 1.5 & 1060 & 75 & 2 & 1117 \\
\hline 6 & 0.42 & 988 & 41 & 1.37 & 1060 & 76 & 3.2 & 1185 \\
\hline 7 & 0.5 & 1090 & 42 & 2.5 & 1056 & 77 & 2.7 & 1132 \\
\hline 8 & 0.35 & 1080 & 43 & 2.15 & 1056 & 78 & 2.6 & 795 \\
\hline 9 & 0.45 & 1100 & 44 & 2.5 & 1079 & 79 & 1.7 & 490 \\
\hline 10 & 0.44 & 978 & 45 & 2.2 & 1148 & 80 & 2.06 & 490 \\
\hline 11 & 0.25 & 917 & 46 & 0.3 & 756 & 81 & 1 & 494 \\
\hline 12 & 0.4 & 959 & 47 & 0.5 & 900 & 82 & 1.5 & 504 \\
\hline 13 & 0.27 & 955 & 48 & 0.36 & 790 & 83 & 1.8 & 642 \\
\hline 14 & 1.4 & 848 & 49 & 0.5 & 747 & 84 & 1.7 & 642 \\
\hline 15 & 1.55 & 870 & 50 & 1.35 & 792 & 85 & 2.1 & 765 \\
\hline 16 & 1.6 & 901 & 51 & 1.1 & 890 & 86 & 2.85 & 1080 \\
\hline 17 & 2.2 & 863 & 52 & 0.5 & 881 & 87 & 2.05 & 1100 \\
\hline 18 & 1.6 & 956 & 53 & 0.5 & 846 & 88 & 2.3 & 1100 \\
\hline 19 & 1.9 & 953 & 54 & 0.85 & 943 & 89 & 1.68 & 1000 \\
\hline 20 & 1.3 & 952 & 55 & 1.18 & 935 & 90 & 1.78 & 1045 \\
\hline 21 & 3.2 & 890 & 56 & 2.6 & 1163 & 91 & 1.2 & 795 \\
\hline 22 & 2.1 & 900 & 57 & 2.1 & 1163 & 92 & 1.7 & 790 \\
\hline 23 & 1.6 & 716 & 58 & 1.1 & 986.2 & 93 & 2.1 & 680 \\
\hline 24 & 1.45 & 612 & 59 & 0.7 & 630 & 94 & 1.13 & 525.4 \\
\hline 25 & 0.99 & 427 & 60 & 1.2 & 738 & 95 & 1.89 & 490 \\
\hline 26 & 1.15 & 435 & 61 & 1.45 & 433 & 96 & 1.81 & 533 \\
\hline 27 & 0.9 & 470 & 62 & 2.4 & 843 & 97 & 1.65 & 533 \\
\hline 28 & 1.6 & 550 & 63 & 1.2 & 738 & 98 & 1.89 & 624 \\
\hline 29 & 1.7 & 597 & 64 & 2.95 & 1000 & 99 & 1.61 & 533 \\
\hline 30 & 0.68 & 600 & 65 & 2.4 & 1072 & 100 & 1.7 & 780 \\
\hline 31 & 0.38 & 369 & 66 & 2.4 & 843 & 101 & 1.85 & 780 \\
\hline 32 & 1.35 & 612 & 67 & 2.6 & 1148 & 102 & 2 & 808 \\
\hline 33 & 1.85 & 693 & 68 & 1.1 & 475 & 103 & 1.25 & 605 \\
\hline 34 & 2.7 & 985 & 69 & 1.5 & 620 & 104 & 1.4 & 545 \\
\hline 35 & 1.07 & 1148 & 70 & 2.62 & 993 & & & \\
\hline
\end{tabular}
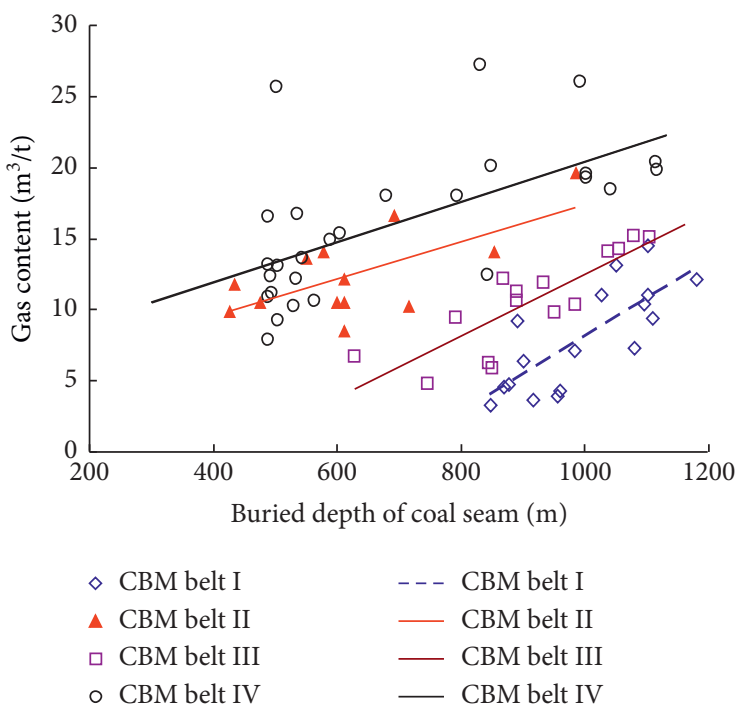

(a)

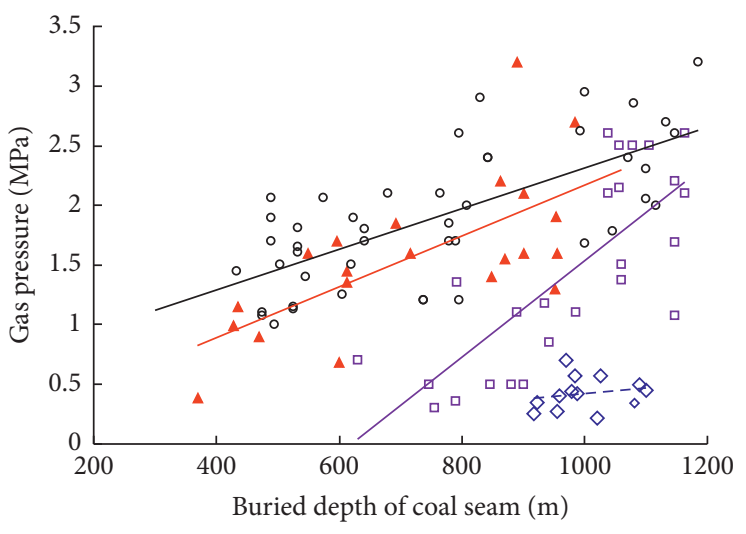

$\diamond \mathrm{CBM}$ belt I

CBM belt II

口 CBM belt III

- CBM belt IV

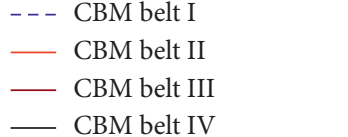

(b)

FIGURE 3: Difference of CBM (gas) occurrence among different CBM belts in coal seam group F showing (a) CBM (gas) content and (b) gas pressure, and these CBM (gas) data were measured actually underground coal mine. 


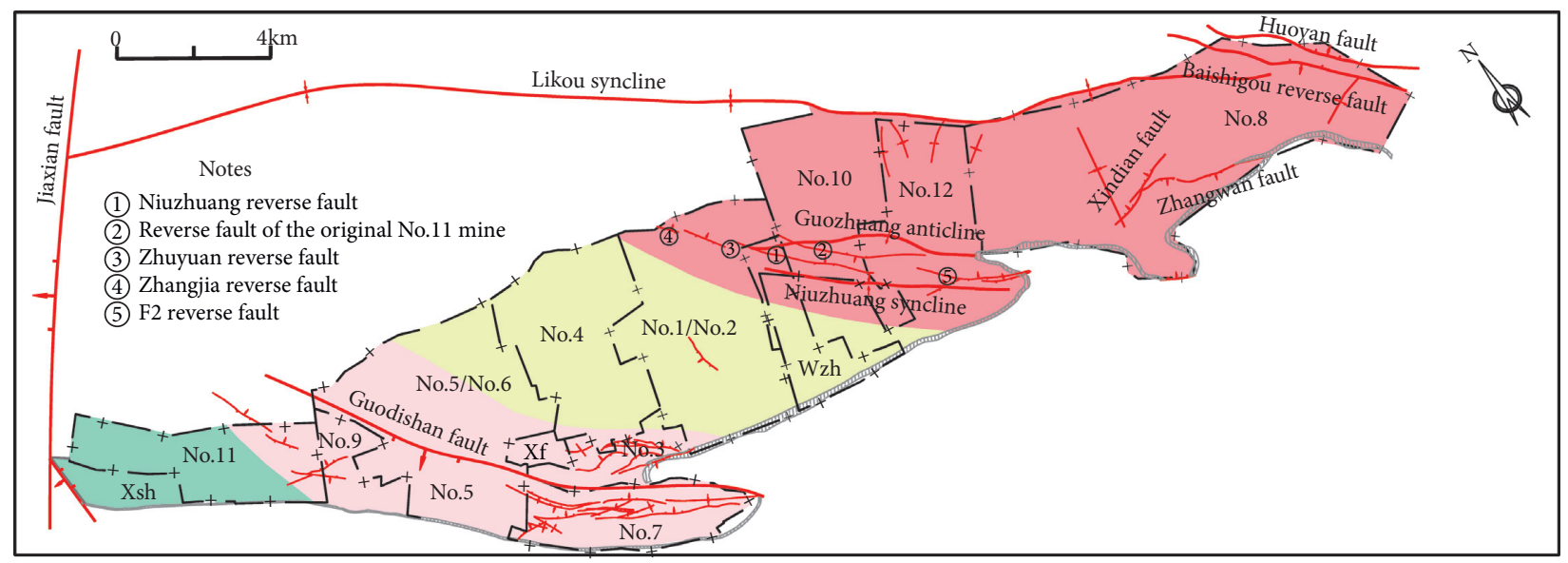

$$
\begin{aligned}
& + \text { Syncline } \\
& + \text { Anticline } \\
& \text { L. Normal fault } \\
& 1 \text { Reverse fault } \\
& \overline{-}^{+-} \text {Boundary of mine } \\
& \text { No.8 Name of coal mine } \\
& \& \text { Wzh Coalbed outcrop }
\end{aligned}
$$

CBM belt I

CBM belt II

CBM belt III

CBM belt IV

(a)

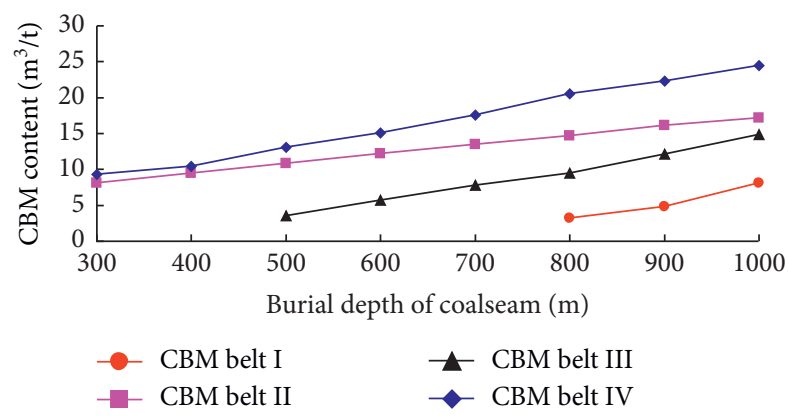

(b)

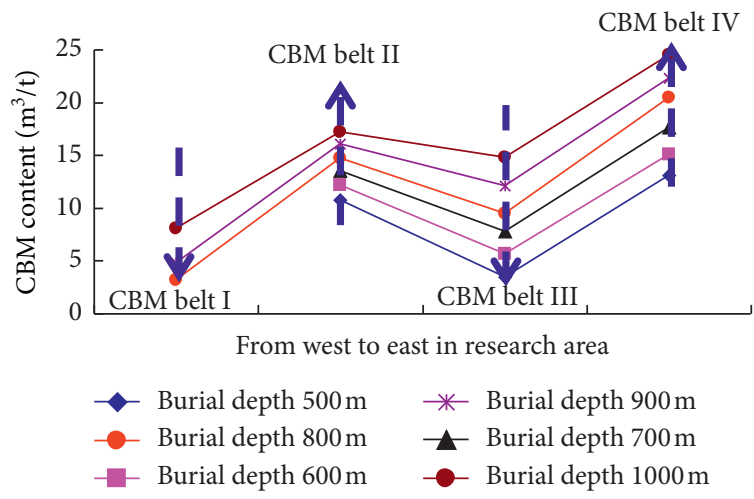

(c)

FIgure 4: The division of CBM belts and the distribution of CBM (gas) content of the research area in coal seam group F showing (a) the division of CBM belts and ((b), (c)) the difference and change of CBM (gas) content among different CBM belts. Figures (b) and (c) were prepared according to the relationship between CBM content and burial depth (Table 3).

CBM belt I and mainly includes the east of No. 11 Mine, No. 9 Mine, the west of No. 5 (No. 6) Mine, No. 7 Mine, and No. 3 Mine. CBM belt III lies in the middle and mainly comprises No. 4 Mine, most part in the west of No. 1 (No. 2) Mine, Wzh Mine, and a small part of the east of No. 5/No. 6 Mine. CBM belt IV lies in the eastern part, No. 10, No. 12, and No. 8 mines and a small part of the east of No. 1 (No. 2). Mine are mainly distributed in this belt.

It shows that there is an overall trend of CBM contents and gas pressures increasing with the increase of the burial depth in the same CBM belt from Figures 3 and 4(b) and Table 2; in particular, there is a great difference of those 
TABLE 2: Statistics and analysis of CBM (gas) content of the research area in coal seam group F.

\begin{tabular}{lccc}
\hline $\begin{array}{l}\text { CBM } \\
\text { belts }\end{array}$ & $\begin{array}{c}\text { Range of CBM content } / \mathrm{m}^{3} / \mathrm{t} \\
(\mathrm{min} \sim \max / \mathrm{avg})\end{array}$ & $\begin{array}{c}\text { Depth range of CBM content } \\
\text { measurement/m }(\mathrm{min} \sim \max / \mathrm{avg})\end{array}$ & $\begin{array}{c}\text { Relationship between CBM content }\left(\mathrm{W} / \mathrm{m}^{3} / \mathrm{t}\right) \text { and } \\
\text { burial depth }(\mathrm{H} / \mathrm{m})\end{array}$ \\
\hline $\begin{array}{l}\text { CBM } \\
\text { belt I }\end{array}$ & $3.32 \sim 14.47 / 8.01$ & $848 \sim 1180 / 996.8$ & $W=0.0271 H-19.043(750<H<1200)$ \\
$\begin{array}{l}\text { CBM } \\
\text { belt II }\end{array}$ & $8.49 \sim 19.58 / 12.44$ & $427 \sim 985 / 626.7$ & $W=0.0131 H+4.2609(300<H<1100)$ \\
$\begin{array}{l}\text { CBM } \\
\text { belt III }\end{array}$ & $4.77 \sim 15.13 / 10.49$ & $630 \sim 1106 / 911.2$ & $W=0.0218 H-9.3485(500<H<1100)$ \\
$\begin{array}{l}\text { CBM } \\
\text { belt IV }\end{array}$ & $7.87 \sim 27.2 / 16.00$ & $489 \sim 1117 / 690.5$ & $W=0.0142 H+6.1924(200<H<1200)$ \\
\hline
\end{tabular}

TABle 3: Statistics and analysis of gas pressure of the research area in coal seam group F.

\begin{tabular}{lccc}
\hline CBM belts & Range of gas pressure number & $\begin{array}{c}\text { Range of gas pressure (MPa) } \\
(\min \sim \max / \mathrm{avg})\end{array}$ & $\begin{array}{c}\text { Depth range of gas pressure measurement }(m) \\
(\min \sim \max / \mathrm{avg})\end{array}$ \\
\hline $\begin{array}{l}\text { CBM } \\
\text { belt I }\end{array}$ & $1 \sim 13$ & $0.22 \sim 0.70 / 0.42$ & $917 \sim 1100 / 999.3$ \\
CBM \\
$\begin{array}{l}\text { belt II } \\
\text { CBM } \\
\text { belt III }\end{array}$ & $14 \sim 34$ & $0.38 \sim 3.20 / 1.58$ & $427 \sim 985 / 723.7$ \\
CBM \\
belt IV
\end{tabular}

among CBM belt I, CBM belt II, CBM belt III, and CBM belt IV. At the same burial depth, CBM contents and gas pressures in CBM belt IV are the highest, followed by CBM belt II. CBM contents and gas pressures of CBM belt I are the lowest. The CBM contents and pressures of CBM belt III are between those of CBM belt II and those of CBM belt I. Each CBM belt shows its own characteristics. Taking the coal seam group $\mathrm{F}$ as an instance, the details are as follows.

In the CBM belt I, the overburden depth of measurement points of CBM contents is $848 \sim 1180 \mathrm{~m}$ with an average of $996.8 \mathrm{~m}$. The gas content is $3.32 \sim 14.47 \mathrm{~m}^{3} / \mathrm{t}$ with an average of $8.01 \mathrm{~m}^{3} / \mathrm{t}$, which is less than $10 \mathrm{~m}^{3} / \mathrm{t}$ within the range of burial depth less than $1000 \mathrm{~m}$. The gas pressure is below $0.7 \mathrm{MPa}$ at the burial depth of not more than $1,000 \mathrm{~m}$. The CBM content and gas pressure are the lowest in this coalfield. But the gas weathering zone of the coalbed is the deepest; it is about $750 \mathrm{~m}$. Xsh Coal Mine is in this gas weathering zone; gas emissions are generally lower than $2 \mathrm{~m}^{3} / \mathrm{t}$ during mining. The CBM content generally increases with the increase of burial depth; their correlation is apparent under $750 \mathrm{~m}$ depth.

In the CBM belt II, the overburden depth of measurement points of CBM contents is $427 \sim 985 \mathrm{~m}$ with an average of $626.7 \mathrm{~m}$. The $\mathrm{CMB}$ content is $8.49 \sim 19.58 \mathrm{~m}^{3} / \mathrm{t}$ with an average of $12.44 \mathrm{~m}^{3} / \mathrm{t}$, which is mostly $10-15 \mathrm{~m}^{3} / \mathrm{t}$, and the gas pressure is mostly $1.2-2.0 \mathrm{MPa}$ with an average of $1.58 \mathrm{MPa}$, which are generally higher than those of the CBM belt I and the CBM belt III and lower than those of the CBM belt IV at the same burial depth. The gas weathering zone of the coalbed is shallow; it is about $300 \mathrm{~m}$. The CBM content generally increases with the increase of burial depth under the depth of coalbed gas weathering zone, but it tends to be relatively dispersed. In addition, the CBM content and gas emissions during mining tend to increase near Guodishan faults (Figure 5). It can be seen clearly from Figures 5(a) and 5(b) that the CBM content increases obviously with the decrease of the distance from the Guodishan fault. The 22021 working face and the 22011 working face lie in the same burial depth about $500 \mathrm{~m}$ (Figure 5(a)). The 22011 working face is closer to the Guodishan fault than the 22021 working face. According to the data of gas emission during mining, the gas emission of 22011 working face is significantly larger than that of 22021 working face. As shown in Figure 5(c), the relative gas emission of the 22011 working face is 9.96 $14.16 \mathrm{~m}^{3} / \mathrm{t}$, and that of the 22021 working face is $5.69 \sim$ $8.61 \mathrm{~m}^{3} / \mathrm{t}$.

In the CBM belt III, the burial depth of measurement points of CBM contents is $630 \sim 1106 \mathrm{~m}$ with an average of $911.2 \mathrm{~m}$. The coal seam demonstrates $4.77 \sim 15.13 \mathrm{~m}^{3} / \mathrm{t}$ of gas content with an average of $10.49 \mathrm{~m}^{3} / \mathrm{t}$. The gas pressure is $0.3 \sim 2.60 \mathrm{MPa}$ with an average of $1.43 \mathrm{MPa}$. It is mostly $0.4 \sim$ $1.5 \mathrm{MPa}$ at the burial depth of not more than $1,100 \mathrm{~m}$. However, gas pressure increases greatly and reaches 1.69 2.6 MPa under the burial depth of $1,100 \mathrm{~m}$. And the gas weathering zone of the coalbed is deeper; it is around $500 \mathrm{~m}$. The CBM content increases with the increase of burial depth under $500 \mathrm{~m}$ depth with good correlation.

In the CBM belt IV, the overburden depth of measurement points of CBM contents is $489 \sim 1117 \mathrm{~m}$ with an average of $690.5 \mathrm{~m}$. The CBM (gas) content ranges from $7.87 \mathrm{~m}^{3} /$ to $27.2 \mathrm{~m}^{3} / \mathrm{t}$ with an average of $16.0 \mathrm{~m}^{3} / \mathrm{t}$, which is mostly $10 \sim 20 \mathrm{~m}^{3} / \mathrm{t}$ and even about $30 \mathrm{~m}^{3} / \mathrm{t}$. The gas pressure is mostly $1 \sim 3 \mathrm{MPa}$. The gas weathering zone of the coalbed is very shallow, which is approximately $200 \mathrm{~m}$. The CBM content generally increases with the increase of burial depth under the burial depth of $200 \mathrm{~m}$, but the trend is also 


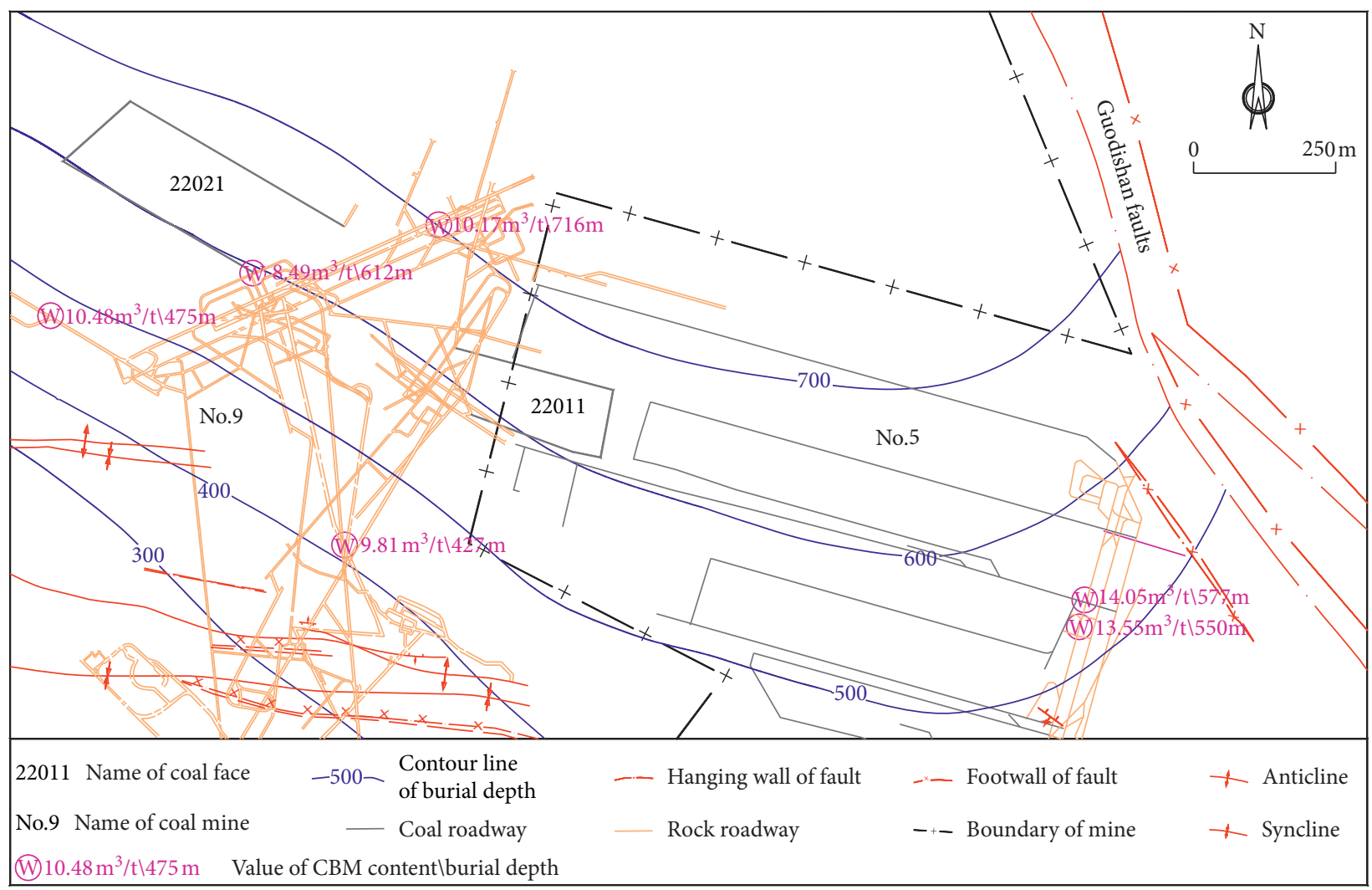

(a)

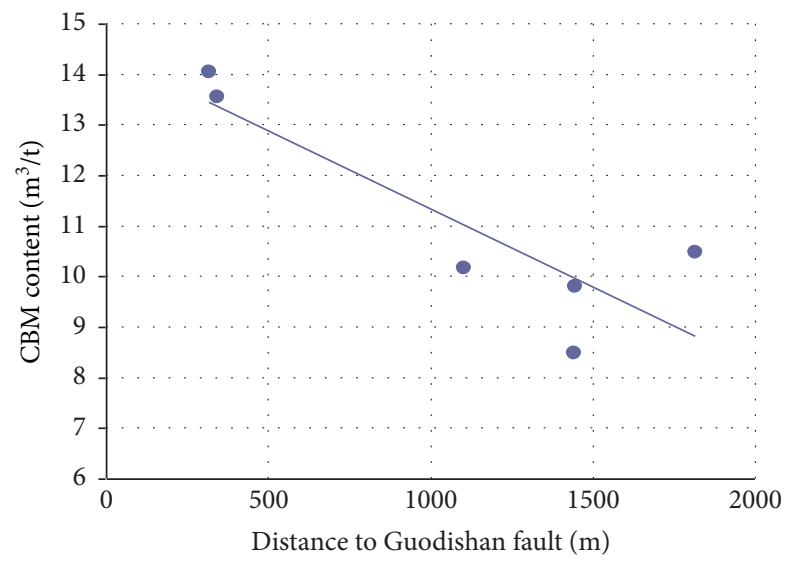

(b)

Figure 5: Continued. 


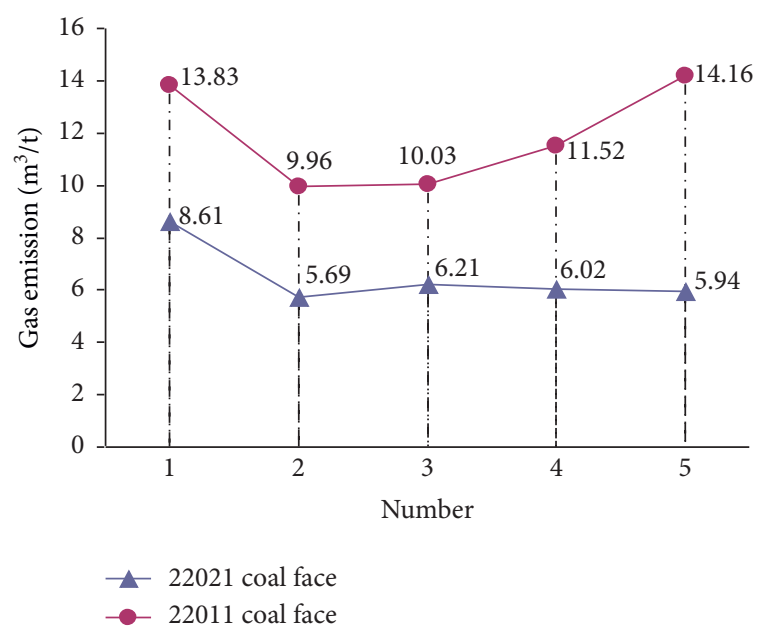

(c)

Figure 5: An example of the variation of CBM content and gas emission of coal seam group F with the distance from Guodishan fault in CBM belt II, showing (a) the structural position of CBM content and coal face near Guodishan fault, (b) the variation of CBM content with the distance from Guodishan fault, and (c) comparison of gas emission between 22021 coal face and 22011 coal face.

relatively scattered. In addition, the CBM content and gas emission during mining increase near the syncline axis or far away from the anticline axis in this belt (Figures 6 and 7).

In addition, the gas content, gas pressure, and gas emission during mining tend to increase near the NWtrending and WNW-trending fault in this coalfield. For instance, the gas content and gas emission in No. 5 Coal Mine and No. 9 Coal Mine near Guodishan fault are higher than those in the middle and western areas far away Guodishan fault at the same burial depth (Figure 5).

\section{Discussion}

4.1. Evolution of Tectonics and Its Influences. The current tectonic framework and type, CBM occurrence, and the distribution of deformed coal are the results of tectonic evolution. Under the action of tectonic movement, coalbearing strata were deformed and displaced by compression, extension, and shear; open and closed faults, folds, and other properties structures were formed, and coal structure was destroyed. And tectonic movement can cause the relative uplift and decline of coal seams. All of those changed the conditions of CBM generation, migration, and preservation in coal seams. The scale, scope, and tectonic stress field of tectonic movement in different periods are different. Due to the different tectonic positions of different areas, coal mining areas, and coal mines, the action intensity of tectonic movement on them is different. Therefore, the present tectonic pattern, CBM occurrence, and deformed coal in different areas, coal mining areas, and coal mines are different, or even very different.

The Pingdingshan Coalfield lies in the south edge belt of the North China plate and also the north side of the thrust and nappe tectonics at the north margin of Qinling orogenic belt $[14,16]$ (Figure 1). The Pingdingshan Coalfield is reformed by the North China plate and has been controlled and reformed by the Qinling orogenic belt for a long time. Since the formation of the Carboniferous-Permian coalbearing strata, the Pingdingshan Coalfield has undergone multistage tectonic movements such as the Indosinian, Yanshanian, Sichuan, North China, Himalayan, and Neotectonic periods [21, 22] (Figure 8). The multiphase tectonic movements affected importantly CBM (gas) occurrence conditions such as tectonic pattern and deformed coal in Pingdingshan Coalfield.

According to the study on the tectonic evolution of Pingdingshan Coalfield in [21], the tectonic movements in various periods have the following main effects on structural formations, coal deformation, CBM formation, and storage in Pingdingshan Coalfield [22-26]. (1) The Pindingshan Coalfield is located at the plate margin, and meanwhile, it is also subjected to long-term squeezing in the south-north direction by the Qinling orogenic belt. The special tectonic location determines the basic features of gas geology in the Pingdingshan Coalfield. The basic features of gas geology are complex geological structures, well-developed deformed coal, and high CBM content. (2) In the Pingdingshan Coalfield, a great amount of coalbed gas was generated during the Indosinian-Yanshan period; the coal-bearing strata experienced severe deformation or displacement during the Sichuan period, which was also the major period for a deformed coal formation; the coalbed gas was mainly released when the NEtrending normal faults were formed during the Sichuan period, and part of the NW-trending reverse faults was transferred to normal faults; the Pingdingshan Coalfield was uplifted in the North China period. (3) The NW- and WNWtrending structures were subjected to squeezing in a longer duration and more intensive activities, compared to the NE-NEN-trending structures. The NW-trending and WNWtrending structures of the whole coalfield are more developed than those of the NE-NEN-trending structures, the deformed coal nearby is more developed, and the conditions of $\mathrm{CMB}$ (gas) preservation are better. 


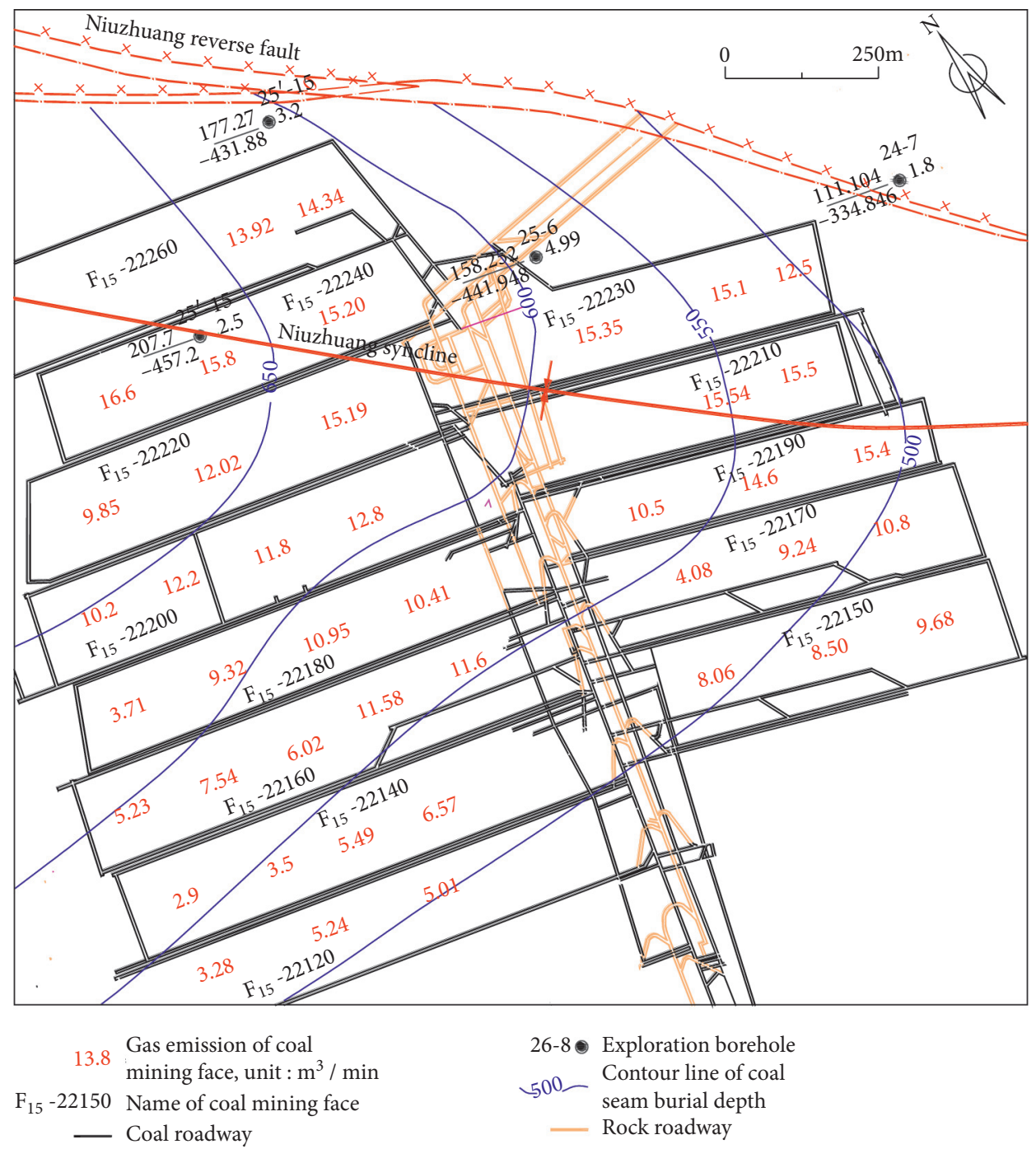

(a)

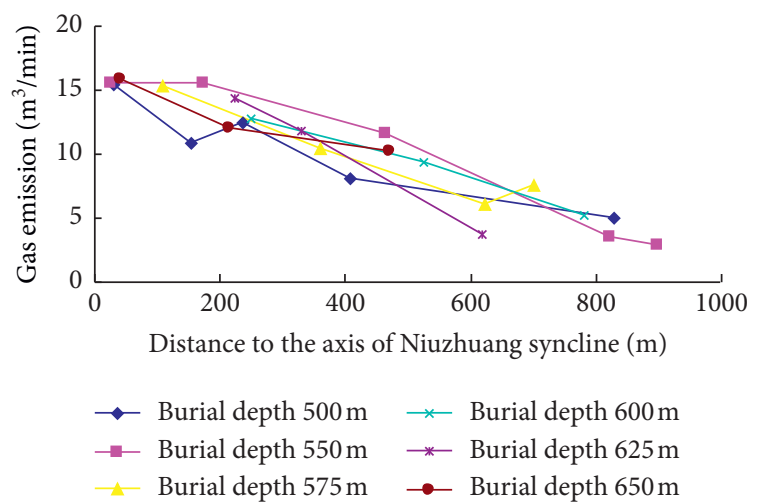

(b)

Figure 6: Continued. 


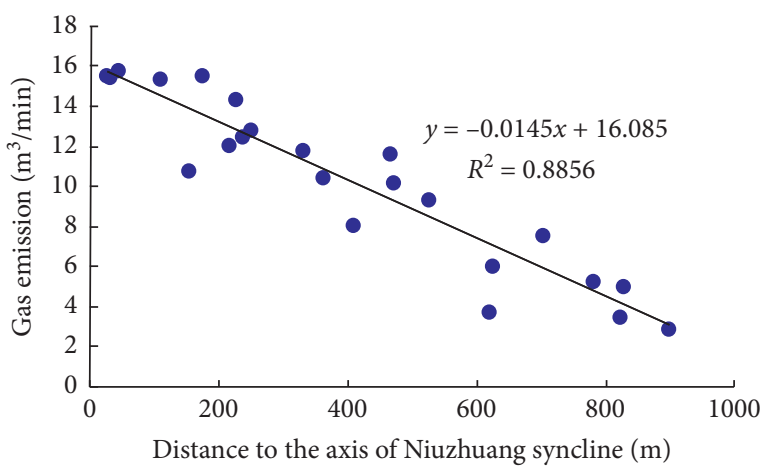

(c)

FIgure 6: The variation of gas emission of coalbed F15 with the distance from Niuzhuang syncline in CBM belt IV.

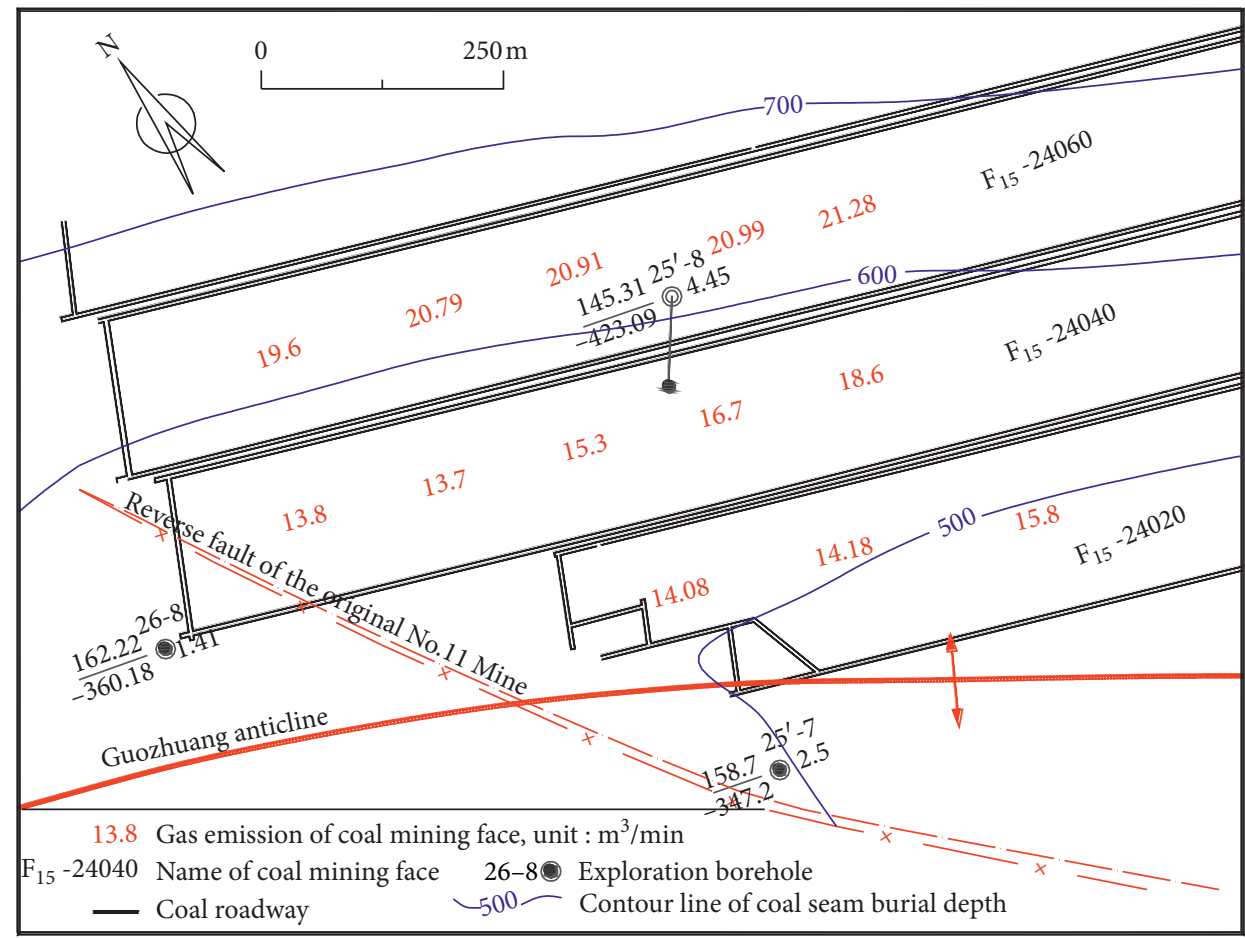

(a)

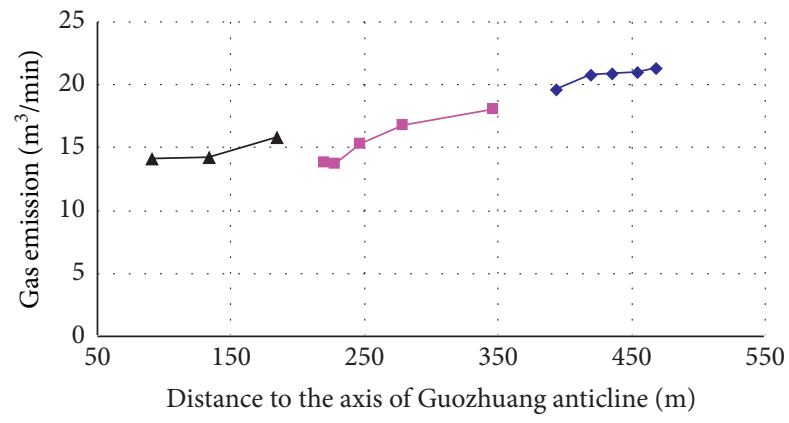

$$
\begin{aligned}
& \longrightarrow \mathrm{F}_{15}-24060 \\
& \rightarrow \mathrm{F}_{15}-24040 \\
& \simeq \mathrm{F}_{15}-24020
\end{aligned}
$$

(b)

FIGURE 7: The variation of gas emission of coalbed F15 with the distance from Guozhuang anticline in CBM belt IV. 

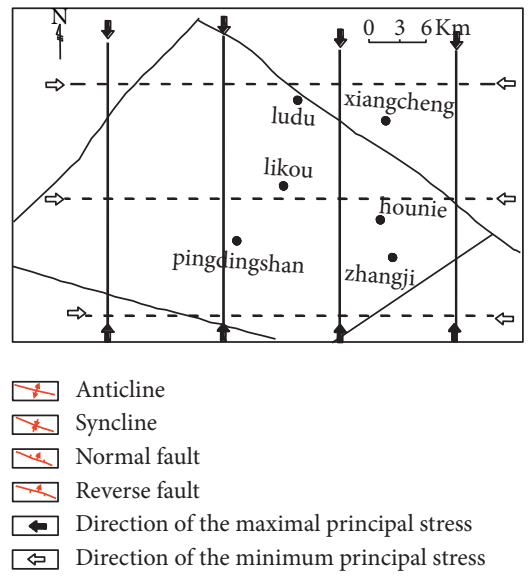

(a)

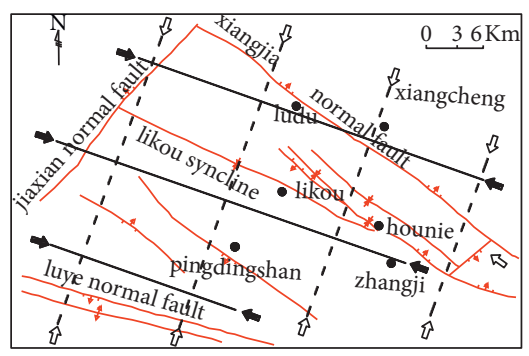

$\square$ Anticline
Syncline
$\square$ Direction of the maximal principal stress
$\square$ Direction of the minimum principal stress

(d)
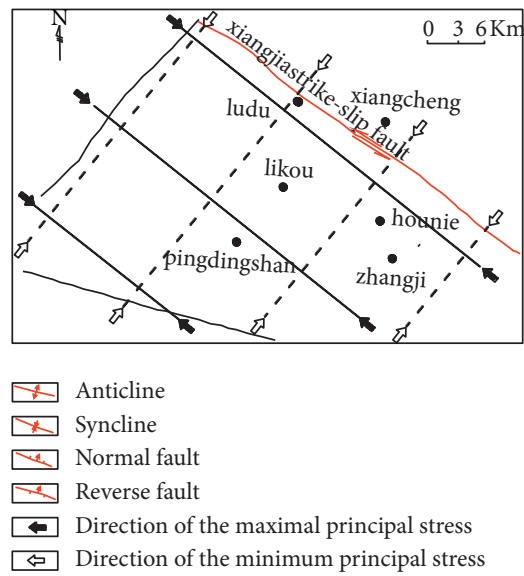

(b)
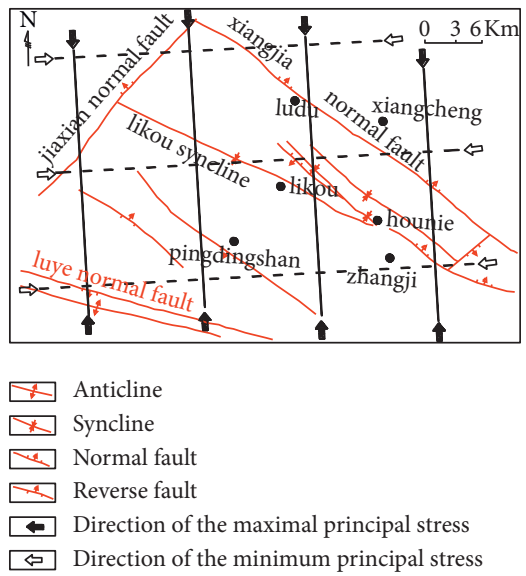

(e)
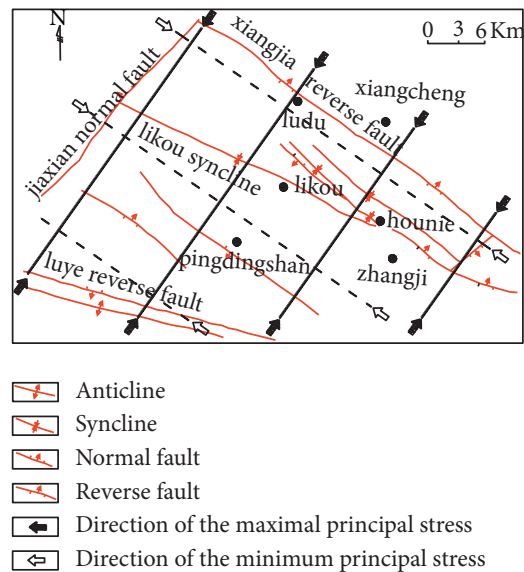

(c)
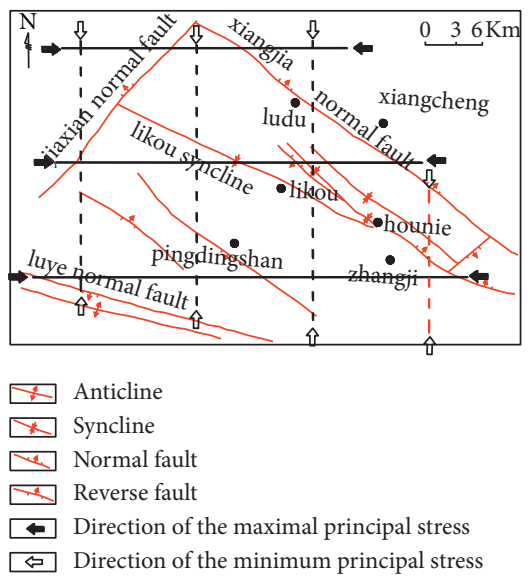

(f)

Figure 8: The evolution of the tectonic of Pingdingshan Coalfield in geological history. (a) Indosinian. (b) Yanshanian. (c) Sichuan period. (d) North China period. (e) Himalaya period. (f) Neotectonic Period.

\subsection{Tectonic Controlling Law for CBM Occurrence}

4.2.1. Tectonic Characteristics of CBM Belts. Under the action of tectonic stresses in various periods, a series of NWtrending and WNW-trending folds and faults were formed in Pingdingshan Coalfield, which were accompanied by NE-NEN-trending faults. Likou syncline is the main control tectonic. But the characteristics of structures in different CBM belts are obviously different (Table 4).

CBM belt I is located in the west of the research area, the wide and gentle area of the Likou syncline. It lies between the Jiaxian fault and the Guodishan fault, near the Jiaxian fault, far away from the Guodishan fault and the axis of the Likou syncline. The controlling structure is the Jiaxian fault. Faults and folds are undeveloped. The geological structure is simple. The structural control type is NE fault structural control type.

CBM belt II is also located in the west of the research area, the wide and gentle area of Likou syncline in the NW direction. It is on both sides of the Guodishan fault, far from the Likou syncline axis, near Guodishan faults, next to CBM belt I in the west. The controlling structure is Guodishan faults. NW- and WNW-trending faults are very developed. It belongs to a complex tectonic zonation. The structural control type is the NW fault structural control type.

CBM belt III is in the middle of the research area. It is in the transition zone from the wide and gentle area in the NW direction to the convergence area in the SE direction. It is far from Guodishan faults and the NW-trending fold-fault belt. This fold-fault belt is composed of Likou syncline, $\mathrm{F}_{2}$ reverse fault, Zhangiia reverse fault, Zhuyuan reverse fault, reverse fault of the original No. 11 Mine, Niuzhuang reverse fault, Guozhuang anticline, and Niuzhuang syncline. The geological structure is relatively simple, with no large controlling structures in this belt. The structural control type is the burial depth control type.

CBM belt IV lies in the eastern part of the research area, the convergence, and the closed area of the Likou syncline in the SE direction. It is near the Likou syncline axis. NW- and WNW-trending folds and reverse faults are well developed. Folds are particularly developed. And NE-trending structures such as Xindian fault as well as composite structures formed by NW-trending and NE-NEN-trending structures such as Jiaozan syncline are also developed. Therefore, this belt belongs to the most complex tectonic zone in the 
TABLE 4: The characteristics of tectonic distribution and control in different CBM belts.

\begin{tabular}{lcccc}
\hline $\begin{array}{l}\text { Name of } \\
\text { CBM belt }\end{array}$ & Tectonic location & $\begin{array}{c}\text { Distance from the } \\
\text { Likou syncline axis }\end{array}$ & Controlling structures & $\begin{array}{c}\text { Geological structure and its } \\
\text { Complexity }\end{array}$ \\
$\begin{array}{lccc}\text { CBM } \\
\text { belt I }\end{array}$ & $\begin{array}{c}\text { In the wide and gentle area of } \\
\text { Likou syncline, near Jiaxian faults }\end{array}$ & Far & Jiaxian faults & Simple \\
$\begin{array}{l}\text { CBM } \\
\text { belt II }\end{array}$ & $\begin{array}{c}\text { In the wide and gentle area of } \\
\text { Likou syncline, near Guodishan } \\
\text { faults }\end{array}$ & Far & Guodishan faults & $\begin{array}{c}\text { NW-trending fault structures are } \\
\text { developed; the geological structure is } \\
\text { more complex }\end{array}$ \\
\hline $\begin{array}{l}\text { CBM } \\
\text { belt III }\end{array}$ & $\begin{array}{c}\text { In the transition zone from the } \\
\text { convergence area to the wide and } \\
\text { gentle area }\end{array}$ & $\begin{array}{c}\text { Between CBM belt } \\
\text { II and CBM belt IV }\end{array}$ & Burial depth & Relatively simple \\
\hline $\begin{array}{l}\text { CBM } \\
\text { belt IV }\end{array}$ & $\begin{array}{l}\text { In the convergence area of Likou } \\
\text { syncline }\end{array}$ & Near & $\begin{array}{c}\text { Likou syncline and NW- } \\
\text { and WNW-trending fold- } \\
\text { fault belt }\end{array}$ & $\begin{array}{c}\text { Fold structures and reverse faults are } \\
\text { developed; the geological structure is } \\
\text { the most complex }\end{array}$ \\
\hline
\end{tabular}

research area. Likou syncline and NW- and WNW-trending fold-fault belts are the main controlling structures. The structural control type is the fold structural control type.

\subsubsection{Effects of Tectonic Types on CBM Occurrence.} Based on the above analysis, four CBM belts in the research area have shown dissimilar tectonic types that have different roles for CBM preservation. This has resulted in the difference in CBM (gas) preservation conditions of each CBM belt in the coal seam.

In detail, the NE-trending Jiaxian fault is a boundary fault and mostly exhibited tension during its evolution process; a great amount of coalbed gas was escaped. The area near the Jiaxian fault is far away from the Likou syncline axis, the structure is simple, and the layer-sliding structure of the coal seam almost cannot be found. Deformed coal is not developed (Figure 9); it can be found only near the faults. Tectonic stress was consumed and released during fault formation. The tectonic stress is small in this area near the Jiaxian fault [21] (Figure 10). All these lead to simple structure conditions and very poor CBM preservation conditions. So, the CBM belt I controlled by the Jiaxian fault shows lower CBM content and gas pressure, deeper gas weathering zone of coalbed, and a good correlation between CBM content and burial depth.

It can be concluded from the evolution of tectonics in Pingdingshan Coalfield that the Guodishan fault was a reverse fault in the early stage, and it became a normal fault after inversion of the stress field in the later stage [21]. There are many NW-trending secondary faults on both sides of this fault, especially in the hanging wall. Its hanging wall is the upthrown side of the reverse fault formed during the Sichuan period and, in addition, is the downthrown side of the normal fault formed during the North China period. The coal seam is seriously damaged by rubbing, and the thickness of the coal seam changes greatly. As a result, in this area near the Guodishan fault, especially the hanging wall, the structure is very complex, deformed coal is very developed, and its thickness changes greatly (Figure 9). The closer to the Guodishan fault, the more complex the structure is, and the more developed the deformed coal is. These faults including the Guodishan fault were mostly subjected to compression during their evolution process. Guodishan fault and its secondary faults are closed faults, which are unfavorable for $\mathrm{CBM}$ release. The closer to the Guodishan fault, the more developed the microfracture and the larger the CBM preservation space. As we know, deformed coal is characterized by low strength, strong CBM adsorption capacity, and fast desorption speed [27-29]. So, the CBM belt II controlled by the Guodishan fault shows that CBM content and gas pressure are higher, the coalbed gas weathering zone is shallower, and the CBM content and gas emissions during mining tend to increase near the Guodishan fault. Because of the complexity of gas-geological conditions, the distribution of CBM content with burial depth is relatively scattered.

The geological tectonics is relatively simple in the CBM belt III. The coal seams are less subjected to strong tectonic compression and shear failure. Deformed coal is not developed (Figure 9). CBM is mainly controlled by the overburden depth, so the correlation between CBM content and burial depth is good. And this area is closer to the Likou syncline axis. The tectonic stress is relatively higher [21] (Figure 10). In situ stress greatly affects the permeability of coalbed; compressional stress decreases the permeability of coalbed and inhibits the migration and diffusion of CBM $[30,31]$. It is conducive to save CBM and easily form CBM enrichment areas in compressional stress areas. All of these make that the CBM in the shallow escapes greatly, and the $\mathrm{CBM}$ in the deep is relatively well preserved in this area. So, the gas weathering zone of the coalbed is at greater depth; the CBM content and gas pressure are relatively higher at under the depth of $1100 \mathrm{~m}$. And the mines in this area have transferred to mines prone to coal-gas outburst with increasing mining depth. Nevertheless, coal-gas outbursts are less severe.

CBM belt IV lies in the convergence area of the Likou syncline. The development of fold structures and the closest to the axis of Likou syncline are its typical feature. This type of structure is easy to form CBM enrichment area. Firstly, this type of structure was formed under the actions of strong thrust-nappe tectonics and rock masses bent and deformed without fracture, which maintains the continuous integrity of the rock mass, showing a closed state throughout. Tectonic stresses of every period remained in the subsequent tectonic evolutions without effective release. It is easy to 


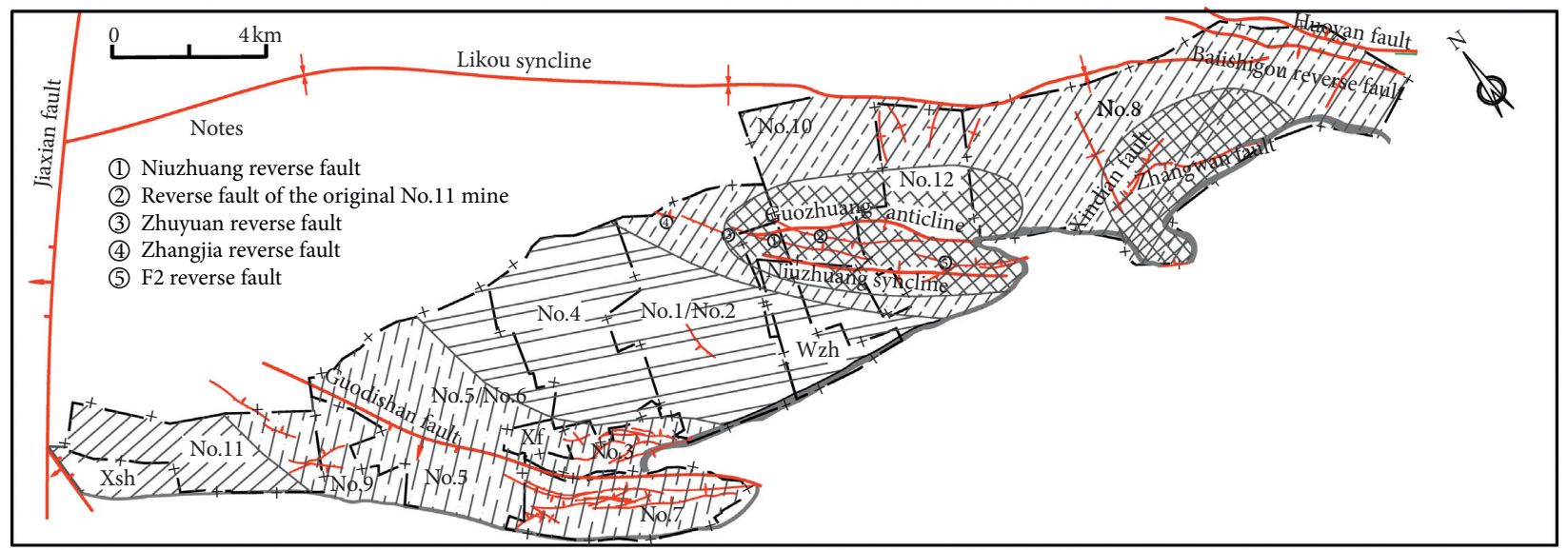

$$
\begin{aligned}
& + \text { Syncline } \\
& + \text { Anticline } \\
& \text { Normal fault } \\
& \text { No.88 } \text { Boundary of mine } \\
& \text { \&Wzh } \text { Name of coal mine } \\
&
\end{aligned}
$$

पIA Less deformed coal

$\sum$ Deformed coal is distributed in part of area

판] Deformed coal is distributed as layer with great thickness change

EIII Deformed coal is distributed as layer in the whole area

Thickness of deformed coal is increased

FIGURE 9: Distribution of deformed coal in the research area, which was prepared according to field investigation.

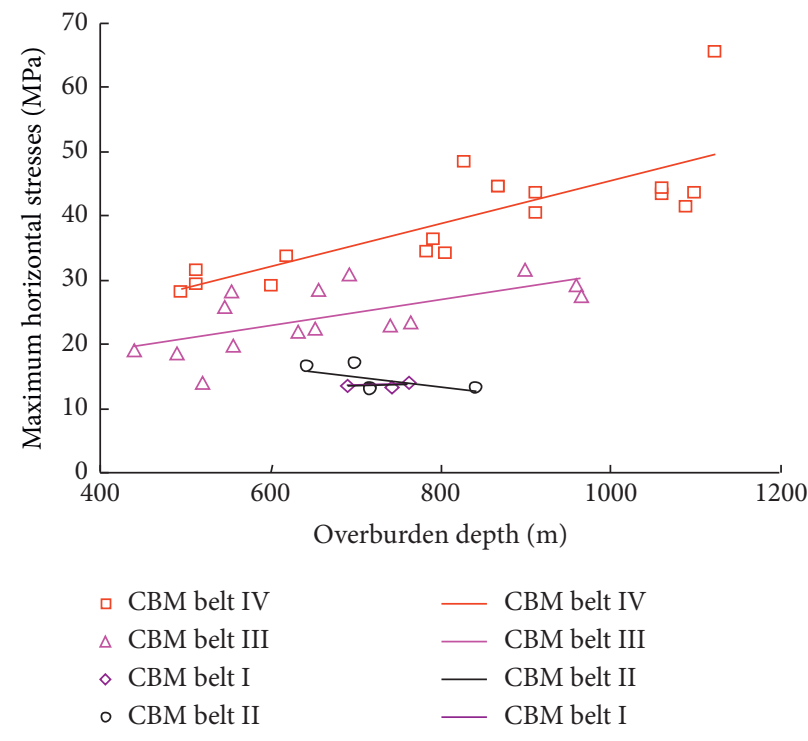

(a)

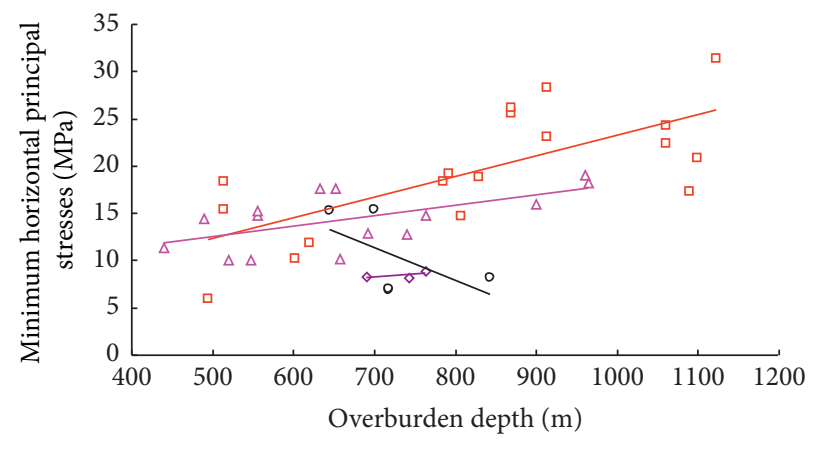

$$
\begin{array}{ll}
\square \text { CBM belt IV } & - \text { CBM belt IV } \\
\triangle \text { CBM belt III } & \text { CBM belt III } \\
\diamond \text { CBM belt I } & \text { CBM belt II } \\
\circ \text { CBM belt II } & - \text { CBM belt I }
\end{array}
$$

(b)

FIGURE 10: Difference of in situ stresses in the four CBM belts, showing (a) maximum horizontal principal stresses and (b) minimum horizontal principal stresses.

form a high-stress zone in the area of fold structure, which is a favorable condition for CBM preservation. In situ stress measurements show that the maximum horizontal stress in this area is generally $30-50 \mathrm{MPa}$ with a maximum of $65.5 \mathrm{MPa}$, which is the largest in this research area (Figure 10). Secondly, during the formation of this type of structure, coal seams as the weaker layers were prone to sliding and deformed coal was formed in layers [32, 33]. In the whole area, deformed coal is distributed as a layer
(Figure 9), which provides a larger space for CBM adsorption and preservation [21, 27, 28]. According to field observation and interpretation of deformed coal by logging curve (Figures 11 and 12), the thickness of deformed coal is generally $1.0 \mathrm{~m}-2.0 \mathrm{~m}$ (Figure 13). Thicker deformed coal was formed in the compound structure area, the wing of the anticline, and the axis of the syncline. For instance, at the NW-trending Niuzhuang syncline, Guozhuang anticline, and former No.11 Mine thrust fault or compound fold area, 


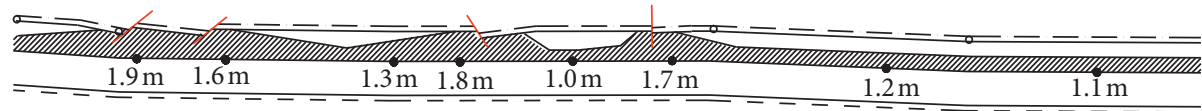

\begin{tabular}{ll} 
Vumala Deformed coal & Coal seam roof \\
\hline Coal seam floor & $1.3 \mathrm{~m}$ Observation point and \\
thickness of deformed coal
\end{tabular}

FIgUre 11: The thickness of deformed coal of C coal seam by field observation in No.8 Coal Mine.

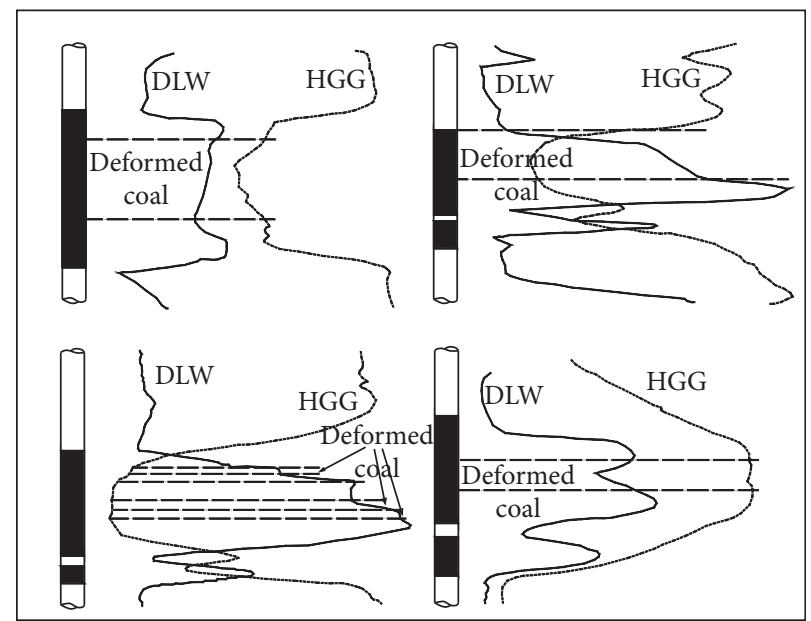

FiguRE 12: Typical example of interpretation for deformed coal by logging curve.

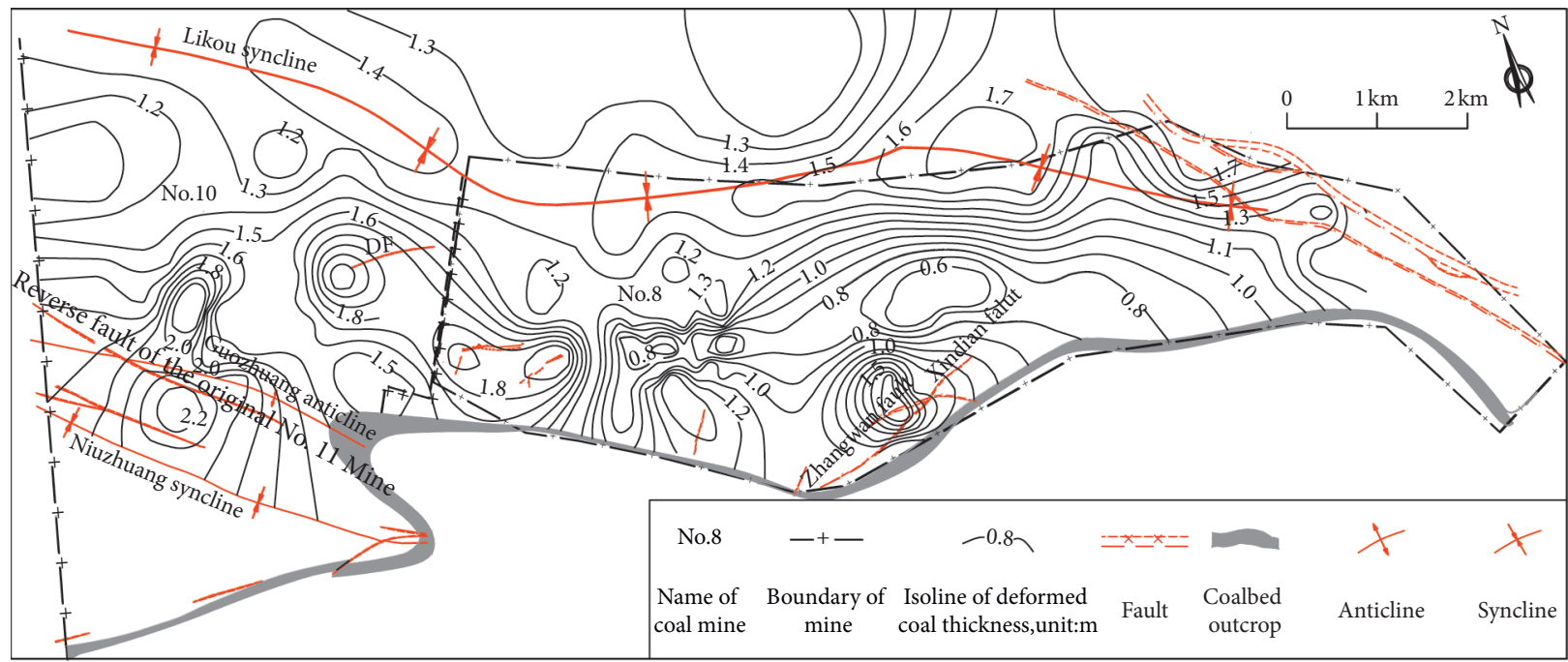

FIGURE 13: Distribution of deformed coal thickness of coal seam group E in the east of research area, which was prepared according to field observation and interpretation of deformed coal by logging curve.

the deformed coal is about $2.0 \mathrm{~m}$ thick. It is $1.5-1.8 \mathrm{~m}$ thick at the north wing of the Guozhuang anticline and $1.5 \mathrm{~m}$ at the axis of the Likou syncline (Figure 13). Thirdly, coal seams were prone to rheology during the formation of the tectonic structure. As a result, thick coal seams were formed which provides a rich material basis for the formation of CBM and a large adsorption space for CBM preservation. For example, the E coal seam in the No. 10 Mine at the north wing of Guozhuang anticline is 5-6 m thick (Figure 14). Finally, this area is near the Likou syncline axis, the burial depth of coal seams is deep, and the overlying bedrock of coal seams is thick. CBM migration to the surface is difficult.

On the whole, the difference of structural types in the east, middle, and west of Pingdingshan Coalfield is the main 

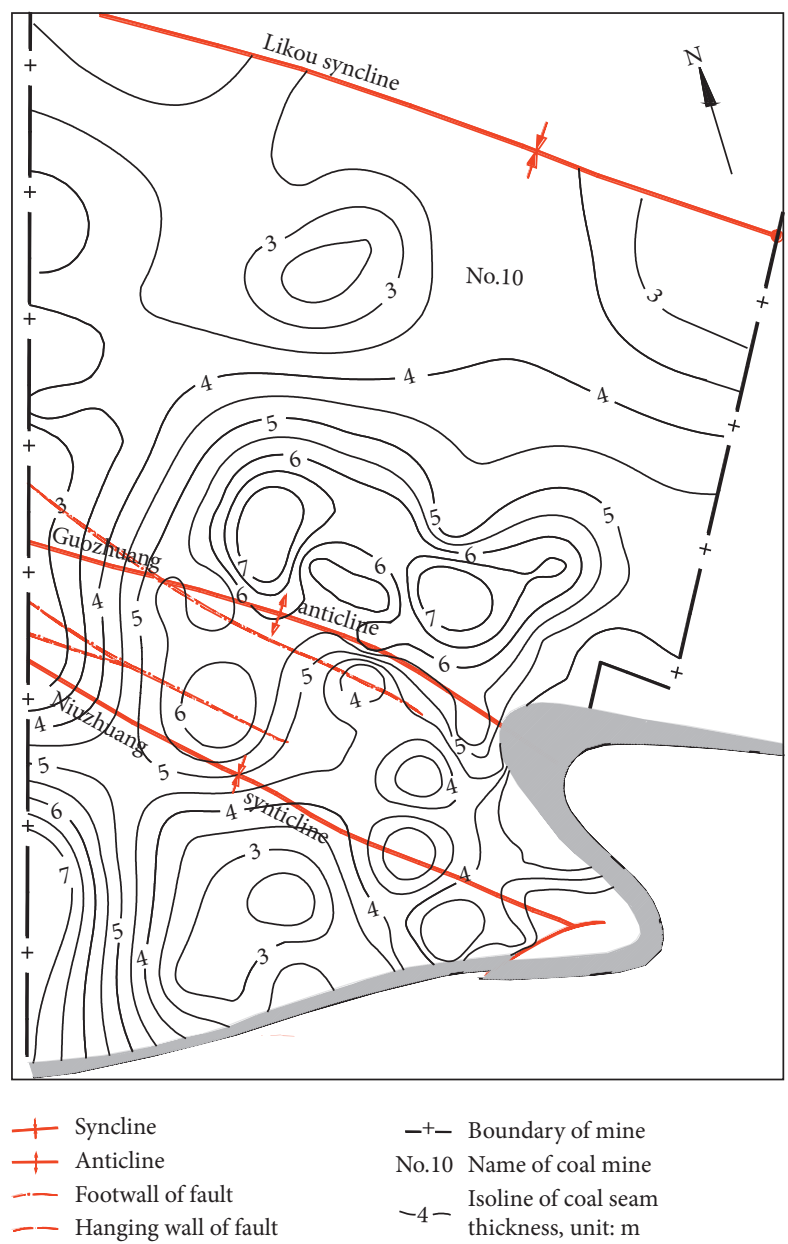

$\begin{array}{cl}\text {-+_ } & \text { Boundary of mine } \\ \text { No.10 } & \begin{array}{l}\text { Name of coal mine } \\ \text { Isoline of coal seam } \\ \text {-4- } \\ \text { thickness, unit: } \mathrm{m}\end{array}\end{array}$

Figure 14: Contour of the thickness of coal seam E in No. 10 Coal Mine.

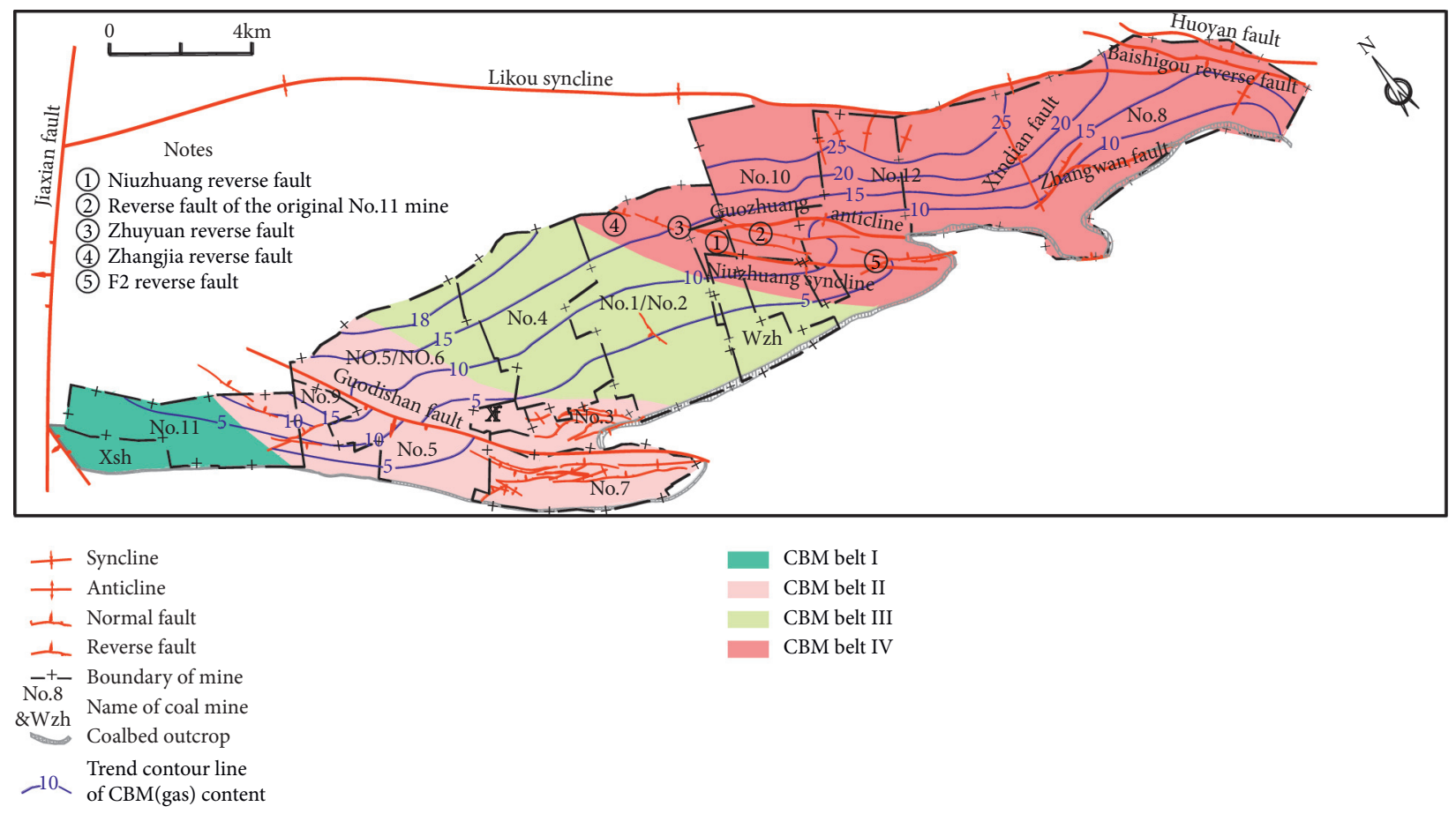

Figure 15: Trend isoline of CBM content of coal seam group F in the research area. 
factor of CBM zoning. Likou syncline is the structure that controls the overall distribution of CBM; the CBM content in the east is obviously larger than that in the west. Guodishan fault, Jiaxian fault, and NW-trending fold-fault belt are the structures that control the local CBM occurrence in the research area.

4.2.3. Prediction of CBM Occurrence. According to tectonic controlling law for CBM occurrence and the relationship between CBM content and burial depth in each CBM belt (Table 2), isoline of CBM content was compiled (Figure 15). The prediction of CBM (gas) content for the unmined area in the deep is an important basis for the exploitation planning of CBM and the prevention and control of coal mine gas disaster. The map of CBM content isoline is also an important reference for the evaluation and development of $\mathrm{CBM}$ resources in abandoned mines in the future.

\section{Conclusions}

(1) Pindingshan Coalfield is located in the plate margin, and meanwhile, it is also subjected to long-term squeezing in the SN direction by the Qinling orogenic belt. The basic features of gas geology in this coalfield are complex geological structures, welldeveloped deformed coal, and high CBM content.

(2) CBM occurrence shows zonation characteristics in the Pindingshan Coalfield. The research area is divided into four CBM occurrence belts. At the same burial depth, CBM belt IV demonstrates the highest CBM contents, followed by CBM belt II. The CBM contents of CBM belt I are the lowest. The CBM contents of CBM belt III are between those of CBM belt II and those of CBM belt I. And each CBM belt shows its own characteristics.

(3) The difference of structural types in the east, middle, and west of Pingdingshan Coalfield is the main factor of CBM zoning. Likou syncline is the structure that controls the overall distribution of CBM. The CBM content in the east is obviously larger than that in the west. Guodishan fault, Jiaxian fault, and NWtrending fold-fault belt are the structures that control the local CBM occurrence in this research area.

(4) CBM content has an overall trend of increasing with the increase of burial depth in the same CBM occurrence belt. Due to the difference of structural types, the variation trend and correlation of CBM content with burial depth are apparently different in different CBM belts. The correlation is apparent in CBM belt I and CBM belt III with a simple structure. The distribution of CBM content with burial depth is relatively scattered in CBM belt II and CBM belt IV with a complex structure.

\section{Data Availability}

The data used to support the findings of this study are included within the supplemental information file(s).

\section{Conflicts of Interest}

The authors declare that they have no conflicts of interest.

\section{Acknowledgments}

This research was financially jointly supported by the National Science and Technology Major Project of China (Grant no. 2011ZX05040005), Key Science and Technology Program of Henan Province (152102210105, 202102310221, and 202102310619), Program for Innovative Research Team at the University of Ministry of Education of China (IRT_16R22), and National Coal Field Engineering Research Center for Gas Geology and Gas Control.

\section{References}

[1] D. P. Creedy, "Geological controls on the formation and distribution of gas in British coal measure strata," International Journal of Coal Geology, vol. 10, no. 1, pp. 1-31, 1988.

[2] R. Gayer and I. Harris, Coalbed Methane and Coal Geology, The Geological Society, London, UK, 1996.

[3] A. Fang, Q. Hou, Y. Ju, Y. Bu, and J. Lu, "A study on control action of tectonic activity on CBM pool from various hierarchies," Coal Geology of China, vol. 17, pp. 15-20, 2005.

[4] C. J. Bibler, J. S. Marshall, and R. C. Pilcher, "Status of worldwide coal mine methane emissions and use," International Journal of Coal Geology, vol. 35, no. 1-4, pp. 283-310, 1998.

[5] K. Frodsham and R. A. Gayer, "The impact of tectonic deformation upon coal seams in the South Wales coalfield, UK," International Journal of Coal Geology, vol. 38, no. 3-4, pp. 297-332, 1999.

[6] J. Tian, "Study on Taihang mountain structure evolution affected to control of gas deposition in Jiaozuo mining area," Coal Science and Technology, vol. 43, pp. 127-130, 2015.

[7] Gas-Geological Laboratory, Institute of Mining Technology in Jiaozuo. Introduction to Gas Geology, China Industry Publishing House, Beijing, China, 1991.

[8] Y. Cao and L. Peng, "Basic types of coal seam faults and their effect on controlling gas outburst zone," Journal of China Coal Society, vol. 20, pp. 413-417, 1995.

[9] Z. Zhang and Y. Zhang, Gas Geology Law and Gas Prediction, Industry Publishing House, Beijing, China, 2005.

[10] Z. Zhang, Y. Lin, and S. Lv, "Distribution of coal seam gas in coal-bearing strata of different periods in China," Earth Science Frontiers, vol. 6, pp. 245-250, 1999.

[11] T. Jia, W. Wang, J. Yan, and C. Tang, "The rule of tectonic and the zoning division of coalmine gas occurrence in Guizhou province," Earth Science Frontiers, vol. 21, pp. 281-288, 2014.

[12] T. Jia, J. Yan, W. Wang, and Z. Zhang, "Tectonic-level-control rule and zone-dividing of coalmine gas occurrence in Liaoning province," Journal of Safety Science and Technology, vol. 10, pp. 24-30, 2014.

[13] T. Jia, W. Wang, and Z. Zhang, "Tectonic control rule and zoning division of coalmine gas occurrence in Yunnan province," Journal of Safety Science and Technology, vol. 10, pp. 42-47, 2014.

[14] Z. Zhang, Gas Geology, China University of Mining and Technology Press, Xuzhou, China, 2009.

[15] Z. Zhang and $\mathrm{Y}$. Wu, "Tectonic-level-control rule and areadividing of coalmine gas occurrence in China," Earth Science Frontiers, vol. 20, pp. 237-245, 2013. 
[16] G. Zhang, B. Zhang, X. Yuan, and Q. Xiao, Qinglingorogenic Belt and Continental Dynamics, Science Press, Beijing, China, 2001.

[17] J. Zhang, The Twelfth Five-Year Plan of Coal Mine Gas Prevention and Control for China Pingmei Shenma Energy \& Chemical Group, China University of Mining and Technology Press, Xuzhou, China, 2009.

[18] K. Wang and F. Du, "Coal-gas compound dynamic disasters in China: a review," Process Safety and Environmental Protection, vol. 133, pp. 1-17, 2020.

[19] C. Xin, F. Du, and K. Wang, "Damage evolution analysis and gas-solid coupling model for coal containing gas," Geomechanics and Geophysics for Geo-Energy and Geo-Resources, vol. 7, p. 7, 2021.

[20] F. Homand, M. Souley, P. Gaviglio, and I. Mamane, "Modelling natural stresses in the arc syncline and comparison with in situ measurements," International Journal of Rock Mechanics and Mining Sciences, vol. 34, no. 7, pp. 1091-1107, 1997.

[21] J. Yan, T. Jia, G. Wei, M. Zhang, and Y. Ju, "In-situ stress partition and its implication on coalbed methane occurrence in the basin-mountain transition zone: a case study of the Pingdingshan coalfield, China," Sadhana, vol. 45, 2020.

[22] T. Wan, Outline of China's Tectonics, Geological Publishing House, Beijing, China, 2004.

[23] M. He, M. Wang, R. Qiu, and D. Yang, Polyphased Superposition Basins and Oil-Gas Resource in the Southern North China Block, Geological Publishing House, Beijing, China, 2012.

[24] X. Guo, Z. Tang, and W. Li, Late Paleozoic Coal Accumulation in Henan Province, China University of Geosciences Press, Beijing, China, 1991.

[25] C. Cui and Y. Cai, "The structure of coalbed methane possession and metamorphil process in Pingdingshan mning area," Journal of Hebei University of Engineering (Natural Science Edition), vol. 17, pp. 67-70, 2000.

[26] G. Wang, Y. Ju, M. Zheng, D. Cao, Y. Qin, and Y. Zhu, Tectonics of Energy Resource Basins in the Northern China, China University of Mining and Technology Press, Xuzhou, China, 2007.

[27] Y. Li, Y. Zhang, Z. Zhang, and B. Jiang, "Experimental study on gas desorption of tectonic coal at initial stage," Journal of China Coal Society, vol. 38, pp. 15-20, 2013.

[28] Y. Zhang, Z. Zhang, and Y. Cao, "Deformed-coal structure and control to coal-gas outburst," Journal of China Coal Society, vol. 32, pp. 281-284, 2007.

[29] J. Han, H. Zhang, Z. Zhu, and J. Song, "Controlling of tectonic stress field evolution for coal and gas outburst in Fuxin basin," Journal of China Coal Society, vol. 32, pp. 934-938, 2007.

[30] J. Ye, B. Shi, and C. Zhang, "Coal reservoir permeability and its controlled factors in China," Journal of China Coal Society, vol. 24, pp. 118-122, 1999.

[31] D. Guo, D. Han, and J. Zhang, "Research on the occurrence and distribution of structural coal in Pingdingshan coal district," Journal of China Coal Society, vol. 27, pp. 249-253, 2002.

[32] J. Yan, W. Wang, and Z. Tan, "Distribution characteristics of gas outburst coal body in pingdingshan tenth coal mine," Procedia Engineering, vol. 45, pp. 329-333, 2012.

[33] J. Yan, Z. Bo, and Y. Yang, "Influence of nanoscale pore on gas adsorption capacity of deformed coal," China Safety Science Journal, vol. 28, pp. 131-136, 2018. 